Mette Hesselholt Henne Hansen is senior lecturer at VIA University College. Her background in evolutionary genetics has fueled a strong interest in quantitative approaches in educational research. She is particularly interested in Education for Sustainable Development (ESD), teaching biodiversity, and the role of inquiry and PBL approaches towards reinforcing scientific literacy.

Martin Krabbe Sillasen is docent in science didactics at VIA University College. He has 22 years' experience with pre- and in-service teacher training. His research interest focuses on science teachers' professional development, teachers' engagement in educational change processes, inquiry based learning, STEM-didactics, Education for Sustainable Development (ESD) and the use of ICT and modelling in science education.

METTE HESSELHOLT HENNE HANSEN

VIA University College, Silkeborg, Denmark

mhhh@via.dk

MARTIN KRABBE SILLASEN

VIA University College, Silkeborg, Denmark

msil@via.dk

\title{
Missing concordance between knowledge and efficacy among Danish science teacher students regarding education for sustainable development
}

\author{
Abstract \\ We conducted a nation-wide survey of Danish science teacher students specializing in science subjects, \\ in order to investigate their knowledge, attitude and self-efficacy on central aspects of education for \\ sustainable development. Our study finds, in accordance with previous publications, a high degree of \\ positive attitude towards the importance of teaching sustainability, and a significant positive correlation \\ between self-efficacy and self-assessed knowledge about the topics in the survey. However, in our study \\ both self-efficacy and self-assessed knowledge correlate negatively with actual knowledge, indicating \\ that some of our participants are subject to an overinflated self-assessment while others may under- \\ estimate their proficiency within the topics. In cognitive psychology, this phenomenon is known as the \\ Dunning-Kruger effect, and we discuss its implications for how best to ensure quality in education for \\ sustainable development in our schools.
}




\section{INTRODUCTION}

Over the last two decades, education for sustainable development (ESD) has gained increased attention worldwide, and this intensified focus is also observed in the Danish educational system. The latest revision of the Common Aims for the public school ("Folkeskolen") posits sustainability as an integrated element in the subjects of primary science, physics/chemistry, biology and geography (Danish Ministry of Education, n.d.). Most recently, sustainability has been integrated in the new interdisciplinary science exam for students finishing lower secondary school at the end of grade 9 (Sillasen \& Linderoth, 2017).

The increased focus on ESD in the Danish educational system is embedded in a global movement to mainstream ESD as an educational approach highlighting democratic, pluralistic and emancipatory elements in teaching to influence student sustainability behavior. This movement was facilitated by the UN Decade of Education for Sustainable Development, administered by UNESCO (Hopkins, 2012). The UNESCO definition of ESD reads:

Education for sustainable development means including key sustainable development issues into teaching and learning; for example climate change, disaster risk reduction, biodiversity, poverty reduction, and sustainable consumption. It also requires participatory teaching and learning methods that motivate and empower learners to change their behavior and take action for sustainable development. Education for sustainable development promotes competencies like critical thinking, imagining future scenarios and making decisions in a collaborative way (UNESCO, n.d.)

According to Boeve-de Pauw, Gericke, Olsson, \& Berglund (2015) interdisciplinarity between the content elements in the definition of ESD is crucial to understanding the complexity of sustainable development, and in the ESD literature this notion is labeled as a holistic approach since it includes multiple perspectives on content (environmental, social and economic). The other essential feature of ESD deals with the pedagogy of teaching and learning which emphasizes action competence for sustainability.

Educational efforts aim to empower students with action competence in order to deal with critical aspects of sustainable development. Action competence is considered as being closely related to ESD, because it aligns well with understanding environmental problems such as societal issues constituted by conflicting interests. Furthermore, action competence adds a democratic action dimension to ESD, which, if this dimension was excluded, would leave ESD as a dogmatic and moralistic concept (Mogensen \& Schnack, 2010).

Concerning the process of integrating ESD in higher education curricula - e.g. teacher training programs - study programs need to be redesigned and new programs created. According to Cincera, Biberhofer, Binka, Boman, Mindt and Rieckmann (2018) there is a need for innovation regarding teaching-learning approaches in ESD. They recommend a competence-based ESD pedagogy that is learner centered, collaborative, inter- and transdisciplinary and based on values and real-world problems.

In this study, we choose to focus particularly on science teacher students, since the natural sciences provide essential subject matter knowledge: Understanding key scientific processes and phenomena is a prerequisite for evaluating causes and effects of actions addressing many sustainable development issues.

At the turn of the new millennium, the 191 member states of the United Nations established eight international goals for sustainable development set for a target of 2015 (United Nations, 2000, 2015b). The project "Teach MDGs" which formed part of the goal strategy, aimed at an inclusion of ESD in the school curricula of member states. 
In 2015 the MDGs were evaluated, and the strategy was intensified and operationalized by posing 17 goals for sustainable development (United Nations, 2015a).

Addressing these goals in schools requires teachers to have solid subject matter knowledge about both the underlying subjects and their interdisciplinary perspectives: evaluating challenges, combining knowledge from several fields, innovating and developing solutions are all activities at the highest levels of our learning taxonomies. To achieve such goals for future generations, teacher education must enable science teacher students to approach the task with adequate knowledge and self-efficacy.

Despite these initiatives by the United Nations, concerns have been raised over the purpose, role and structure of ESD in national educational programmes (Dillon, 2014). One of the challenges stems from the concept of sustainability being defined by the very broad phrasing in the report by the Brundtland commission set by the United Nations (Brundtland, 1987). The Brundtland report defined sustainability as: Development that meets the needs of the present generation without compromising the ability of future generations to meet their own need". This broad definition can mask issues and conflicts of interest involving environmental, social and economic matters in the general population (Dillon, 2014). A Swedish study (Borg, Gericke, Höglund, \& Bergman, 2014) shows that this is an issue for teachers in particular. The Swedish teachers in the study generally acknowledge the relevance of an interdisciplinary approach to ESD. However, their understanding of the concept remains rooted in their subject tradition, leading social science teachers to emphasize social dimensions and science teachers to emphasize ecological dimensions. This situation is likely to be similar in Denmark. Scott, Gough and Chalmers (2003) argue that having distinctive perspectives can bring distinct learning opportunities, provided that teachers do not foreclose the interdisciplinary nature of sustainability by advocating the view representing their own subject field against all others. Other challenges for integrating sustainability in schools may include teachers' attitudes towards ESD and their own interdisciplinary subject matter knowledge about sustainability.

In Denmark, there is a long-standing tradition for environmental education (EE) occupying a prominent position in science teachers' practice (Breiting \& Wickenberg, 2010). In the literature, ESD is seen as a natural extension of EE (Dillon, 2014). For many years, teachers with a personal interest and engagement in environmental issues were drivers of EE in Danish schools. However, despite a large effort to implement EE, the topic has never mainstreamed in the school curriculum. Recently, the situation is changing, largely due to the focus on the UN sustainability goals, and ESD is gaining importance as a central element in the school curriculum.

Solid knowledge regarding ESD is rare in the literature, particularly in the Danish context. One study (Clausen, 2018) investigates self-assessed knowledge of Danish geography teachers regarding various topics within their subject field and pedagogical methodologies. In Clausen's study, knowledge regarding sustainable development ranked among the top topics in the teacher's self-assessment, while the low scorer was knowledge of the nature of science. That study did not test actual knowledge.

In this study, we focus particularly on the science teacher students' efficacy and subject matter knowledge towards ESD, because alignment between these two components is a prerequisite for high quality teaching. Efficacy beliefs have been described as being constructed from mastery experiences, vicarious experiences, social persuasion and emotional arousal (Bandura, 1986). For science teacher students, mastery and vicarious experiences rely on positive experiences gained by experimenting with ESD in practice situations or observing experienced teachers in practice. A recent review of strategies that support teacher professional learning provides evidence that integrating teaching practices into teacher training is a powerful tool for science teacher students' learning processes (Nielsen, 2017). A recent study also indicates that science teacher students increase their self-efficacy by working with interdisciplinary science issues, such as ESD, in practice situations (Flores, 2015). Bandura also considers social persuasion and emotional arousal important sources of efficacy. Given the potential lack of mastery experiences and possibilities for vicarious experiences of ESD for science teacher students, social persuasion and emotional arousal may play a more dominant role in developing science teach- 
er students' attitude towards ESD. An Australian study investigated Bandura's concept of efficacy through an exploratory factor analysis, and found two main factors underlying the students' persuasion: perceived importance of ESD, and self-efficacy towards teaching ESD. The study also investigated perceived and actual knowledge about key science concepts relating to ESD, and showed that the self-efficacy of science teacher students towards ESD increased with increased levels of perceived knowledge. However, perceived and actual concept knowledge were uncorrelated (Effeney \& Davis, 2013), indicating that science teacher students are willing to engage in ESD for emotional reasons even if they lack subject matter knowledge regarding sustainability.

We found the lacking correlation in the Australian study intriguing, and observed a scarcity of studies investigating the relationship between science teacher students' self-efficacy and their subject matter knowledge of ESD. This led us to the research question guiding this study: what is the connection between science teacher students' self-efficacy, attitude and knowledge about central ESD concepts? A lack of connection between these would indicate a compelling need to evaluate how we train science teacher students in the subject matter knowledge underlying ESD.

\section{METHODS}

We aimed to ensure comparability of our results with previous studies of attitudes and efficacy in the context of ESD (Effeney \& Davis, 2013; OECD, 2009). To this end, we used a modified version of the survey tool from Effeney and Davis (2013) inspired by (Boon, 2011) with some of the survey questions adapted to a Danish context. The survey tool consists of an anonymous questionnaire addressing behaviour, intention and attitude towards teaching sustainability. Boon developed the instrument in light of Ajzen's theory of planned behavior (Ajzen \& Fishbein, 2005) which posits that one's behavior is influenced by intention, which in turn is influenced by attitude and beliefs (See figure 1).

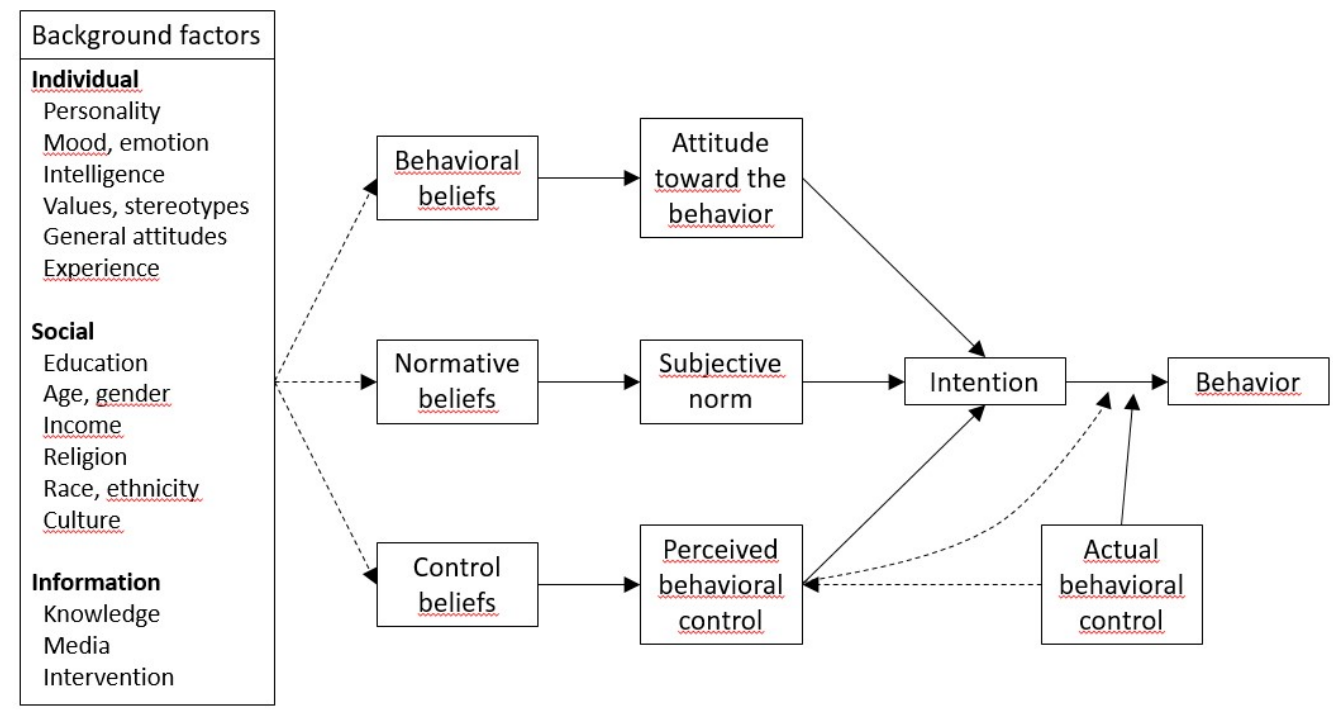

Figure 1: Behavior model of the Theory of planned behavior (Ajzen and Fishbein, 2005, p. 104)

In this modified version of Effeney and Davis' instrument, we designed the first seven questions to reflect self-efficacy (Q1-Q4) and importance of education for sustainable development (Q5-6-7). The entire survey instrument is provided in appendix 1, translated into English. 
Participants in the study are science teacher students attending course programs within the natural sciences at the end of year 2-3-4. The sample includes students qualifying for teaching at lower secondary level within combinations of the following subjects: physics/chemistry, biology and geography. Using a convenience sample strategy, we distributed our survey to science programs at all six university colleges offering teacher education in Denmark. In total, our sample consists of 111 respondents with a gender distribution of $58 \%$ female and $42 \%$ male participants. The potential population for this survey includes 1141 teacher students, consisting of students starting their science subject in 2016 or 2017 (Data retrieved from Association of Danish University Colleges ). This corresponds to a response rate of $9.7 \%$ of the potential number of participants.

\section{ANALYSIS AND RESULTS}

Statistical analysis were performed with the lavaan package in RStudio, Version 1.2.5033 (Rosseel, 2012). As we based our survey tool on the one used in Boon (2011) and Effeney and Davis (2013), we performed a confirmatory factor analysis to obtain goodness of fit measures with the factorized model in Effeney and Davis (2013) for factors representing 1) self-efficacy and 2) perceived importance of teaching sustainable development. The model is illustrated in figure 2 with standardized factor loadings to each of the two factors and model fit indices. Our analysis confirmed good fit to the Effeney and Davis model as evaluated by a RMR of 0.032 (recommended cut off for good fit at $<0.08$ (Prudon 2015)).

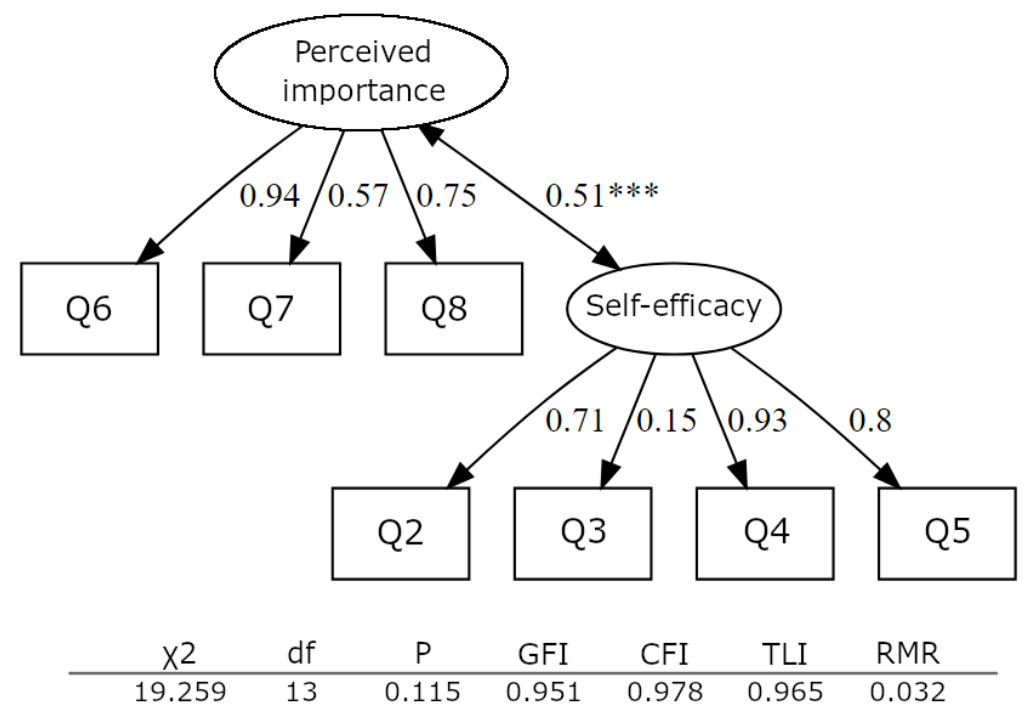

Figure 2: Model of confirmatory factor analysis, fitting the model from Effeney and Davis (2013).

We extracted the principal component for self-efficacy and importance of education for sustainable development from our factor analysis to allow us to explore correlations between these and the scores for perceived and actual knowledge. Reliability analysis of the extracted principle components yielded Cronbach's alpha values of 0.700 for self-efficacy and 0.789 for importance. Using the principal components in the correlation analysis provides a more accurate variable extraction than simply using the aggregate score for this variable, since the factor loadings are taken into account (Holland, 2008). 
Table 1: Perceived importance of teaching sustainability

\begin{tabular}{|c|c|c|c|c|c|}
\hline & $\begin{array}{l}\text { Strongly } \\
\text { agree }\end{array}$ & Agree & Neutral & Disagree & $\begin{array}{l}\text { Strongly } \\
\text { disagree }\end{array}$ \\
\hline $\begin{array}{l}\text { Q5: It is important to teach } \\
\text { environmental education in schools }\end{array}$ & $65(59 \%)$ & $\begin{array}{l}38 \\
(34 \%)\end{array}$ & $\begin{array}{l}5 \\
(5 \%)\end{array}$ & $\begin{array}{l}3 \\
(3 \%)\end{array}$ & 0 \\
\hline $\begin{array}{l}\text { Q6: As teacher I can play an } \\
\text { important role in solving } \\
\text { environmental challenges through my } \\
\text { teaching }\end{array}$ & $28(25 \%)$ & $\begin{array}{l}52 \\
(47 \%)\end{array}$ & $\begin{array}{l}25 \\
(23 \%)\end{array}$ & $\begin{array}{l}6 \\
(5 \%)\end{array}$ & 0 \\
\hline $\begin{array}{l}\text { Q7: It is important to teach } \\
\text { students about the } \\
\text { environment from the earliest } \\
\text { grades }\end{array}$ & $54(49 \%)$ & $\begin{array}{l}47 \\
(42 \%)\end{array}$ & $\begin{array}{l}8 \\
(7 \%)\end{array}$ & $\begin{array}{l}2 \\
(2 \%)\end{array}$ & 0 \\
\hline
\end{tabular}

Q8 to Q12 explored the perceived knowledge of sustainability issues, while Q13 to Q22 aimed to establish actual knowledge of the same issues. Our questions were modelled on Effeney and Davis (2013), but were modified to reflect a Danish sustainability context, and bring them more in line with topics in the Danish school curriculum: We broadened the topic "greenhouse gases" to "climate change" and modified "pollution" to "emission of substances to nature". We replaced "nuclear waste" with "energy supply", since there is no nuclear power production in Denmark. (Refer to appendix 1 for the complete survey instrument).

We scored sums for each category of questions to form an aggregate score for perceived and actual knowledge.

To explore the relationships between efficacy, importance of ESD, and perceived and actual knowledge, we calculated the Pearson correlation coefficients.

The Pearson correlation coefficients revealed a strong and highly significant positive correlation between self-efficacy and perceived knowledge (o.692). The correlation between perceived knowledge and importance of ESD was moderately positive (0.401). We found a moderate but highly significant negative correlation between perceived and actual knowledge (-0.327), and between self-efficacy and actual knowledge (-0.325). Importance of ESD and actual knowledge were similarly negatively correlated (-0.331) (See table 2$)$. 
Table 2: Pearson correlations between actual knowledge score, perceived knowledge score and selfefficacy.

\begin{tabular}{|l|l|l|l|l|}
\hline & $\begin{array}{l}\text { Actual knowledge } \\
\text { score }\end{array}$ & $\begin{array}{l}\text { Perceived } \\
\text { knowledge score }\end{array}$ & $\begin{array}{l}\text { PCA for self- } \\
\text { efficacy }\end{array}$ & $\begin{array}{l}\text { PCA for importance } \\
\text { of ESD }\end{array}$ \\
\hline $\begin{array}{l}\text { Actual knowledge } \\
\text { score }\end{array}$ & 1 & $-0.327^{* *}$ & $-0.325^{* *}$ & $-0.331^{* *}$ \\
\hline $\begin{array}{l}\text { Perceived knowledge } \\
\text { score }\end{array}$ & 1 & $0.692^{* *}$ & $0.401^{*}$ \\
\hline \begin{tabular}{l} 
PCA for self-efficacy \\
\hline $\begin{array}{l}\text { PCA for importance } \\
\text { of ESD }\end{array}$
\end{tabular} & & 1 & $0.559^{* *}$ \\
\hline
\end{tabular}

\section{DISCUSSION}

We set out to investigate the connection between science teacher students' self-efficacy, perceived importance of ESD and their knowledge about central sustainability concepts, motivated by a conviction that these factors are important prerequisites for quality in ESD.

Our survey was successfully able to monitor both attitude and self-efficacy as demonstrated by the confirmatory factor analysis, which produced a strong factor loading for each survey question to these two theoretical variables. However, for one particular survey question, our results differ from earlier studies using this survey tool. Question 2 ("I cannot include education for the environment in my teaching because it needs to be taught by specially trained teachers") was previously found to load strongly to self-efficacy (Boon, 2011; Effeney \& Davis, 2013), but in our study it did not produce any significant factor loading. This could be due to a different tradition in teacher training: In both Australian studies, survey participants receive training as class teachers without any subject specialization. In Denmark, the situation is different, with teachers at all levels specializing as subject teachers. All science teacher students in our study are specializing in science subjects, and consequently they may in fact regard themselves (with some justification) as "specially trained teachers". Since we based our correlation analysis on principal components for self-efficacy and perceived importance, the low factor loading of this question was accounted for through the parameter extraction (Holland, 2008)

In their 2013 study, Effeney and Davis find that Australian science teacher students demonstrate a strong positive correlation between self-efficacy and perceived knowledge, while neither of the two are correlated with actual knowledge. Our study confirms the first point, but in our case we find that self-efficacy, importance of education for sustainable development and perceived knowledge have a significant negative correlation with actual knowledge (first row of table 2).

This phenomenon of inflated self-assessment is well known from cognitive psychology as the Dunning-Kruger effect (Dunning, 2011). Novices in a field tend to overestimate their own proficiency and to fail to recognize the complexity of topics with which they are only superficially acquainted. At the other end of the distribution, those with advanced levels of understanding of complex topics tend to underestimate their own proficiency. A recent paper (Sanchez \& Dunning, 2018) describes how this "beginner's bubble" of overconfidence can lead to errors of judgement in solving complex tasks. This observation holds important implications for the connection between quality in ESD in our schools, and the way we train our science teacher students for the complex task of teaching ESD. 
While our study clearly highlights the need to focus on quality of teacher training in ESD, we find some reassurance in the moderate strength of the observed correlations (first row of table 2), which indicates that a subset of students do self-assess their knowledge in concordance with their actual understanding of the topics. It is possible that students with high self-assessed knowledge and confidence were more likely to complete the survey, thus leading to an emphasis of the Dunning-Kruger effect within this group.

The strong positive correlation between self-efficacy, attitude and perceived knowledge indicates, in accordance with Effeney and Davis (2013) that Danish science teacher students are emotionally willing to engage in ESD, establishing a positive starting point for improving quality of ESD in Danish teacher training programs. The teacher students' emotional willingness to engage in ESD might support them in overcoming potential frustrations of teaching sustainability once they learn about the complexity of sustainable development including content from environmental, social and economic perspectives. As suggested in the literature, this frustration can be addressed by introducing teacher students to teaching strategies that emphasize action competence. Dealing with sustainability problems through participatory action can engage young learners in a constructive way in the complex and conflicting aspects of environmental problems. The challenge for teachers then becomes teaching ESD through authentic examples that represent the complexity of sustainable development in a pedagogical way, enabling young learners to train their action competence without diminishing their belief that sustainable development challenges can be successfully dealt with.

The relatively low response rate $(9.7 \%)$ is an issue when considering the generalizability of our results. Basing our data collection on convenience sampling generates possible biases regarding which students choose to respond. The correlations we found were strongly significant, and as such, our demonstration of an inflated self-assessment among a group of the science students in very convincing. However, the unsampled population, representing those teacher students who did not respond to our survey, may include a greater representation of students with a more accurate self-assessment. Even if this should be the case, our study still demonstrates the phenomenon of missing concordance between self-efficacy and actual knowledge among a group of science teacher students.

Assessing knowledge of complex topics relating to ESD through the score on a multiple choice test does not offer any detailed insights into the teacher students' understanding of central concepts and challenges. We propose to explore the results in this paper further through an intervention study, where we combine quantitative and qualitative research tools to investigate how we can strengthen conceptual understanding and pedagogical concept knowledge through a focused intervention in an interdisciplinary teacher training program. By using the survey tool from this study as a pre- and post-test of the science teacher students in our intervention we will be able to evaluate the effect of a more detailed treatment of a central sustainability topic on subject matter knowledge, attitude and self-efficacy.

\section{ACKNOWLEDGEMENTS}

We would like to thank Professor Bernt Guldbrandtsen from University of Bonn for very helpful discussions about the quantitative analysis and Katie Benson for a linguistic quality check of our manuscript.

\section{REFERENCES}

Ajzen, I., \& Fishbein, M. (2005). The Influence of Attitudes on Behavior. In D. Albarracin, B. Johnson, \& M. Zanna (Eds.), Handbook of attitudes and attitude change: basic principles (pp. 173-221). New York: Lawrence Erlbaum. doi: 10.1126/science.1411548

Bandura, A. (1986). Social foundations of thought and action. New Jersey: Englewoods Cliffs. 
Boeve-de Pauw, J., Gericke, N., Olsson, D., \& Berglund, T. (2015). The Effectiveness of Education for Sustainable Development. Sustainability, 2015, 15693-15717. doi: 10.339o/su71115693

Boon, H. (2011). Beliefs and education for sustainability in rural and regional Australia. Education in Rural Australia, 21(2), 37-51. Retrieved January $13^{\text {th }}$, 2020, from https://search.informit. com.au/documentSummary; dn=775629989523316;res=IELAPA

Borg, C., Gericke, N., Höglund, H. O., \& Bergman, E. (2014). Subject- and experience-bound differences in teachers' conceptual understanding of sustainable development. Environmental Education Research, 2O(4), 526-551. doi: 10.1080/13504622.2013.833584

Breiting, S., \& Wickenberg, P. (2010). The progressive development of environmental education in Sweden and Denmark. Environmental Education Research, 16(1), 9-37. doi: 10.1080/13504620903533221

Brown, J. D. (2009). Choosing the right number of components or factors in PCA and EFA. JALT Testing \& Evaluation SIG Newsletter, 13(2). Retrieved January $13^{\text {th }}, 2020$, from http://hosted. jalt.org/test/bro_3o.htm

Brundtland, G. (1987). Our common future: Report of the 1987 World Commission on Environment and Development. Oslo.

Cincera, J., Biberhofer, P., Binka, B., Boman, J., Mindt, L., \& Rieckmann, M. (2018). Designing a sustainability-driven entrepreneurship curriculum as a social learning process: A case study from an international knowledge alliance project. Journal of Cleaner Production, 172, 43574366. doi: 10.1016/j.jclepro.2017.05.051

Clausen, S. W. (2018). Danish geography teachers assessment of own teacher professionalism In A. Pálsdóttir (Ed.), Science competencies for the future - Proceedings of the 12th Nordic Research Symposium on Science Education June 7th-9th 2017 Trondheim, Norway (pp. 26-34). Trondheim.

Danish Ministry of Education. (n.d.). Common Aims. Retrieved November 2, 2018, from https:// www.emu.dk/omraade/gsk-lærer

Dillon, J. (2014). Environmental education. In N. G. Lederman \& S. K. Abell (Eds.), Handbook of Research in Science Education (pp. 497-514). New York: Routledge.

Dunning, D. (2011). The Dunning-Kruger Effect: On Being Ignorant of One's Own Ignorance. Advances in Experimental Social Psychology, 44, 247-296. doi: 10.1016/B978-0-12-3855220.00005-6

Effeney, G., \& Davis, J. (2013). Education for Sustainability: A Case Study of Pre-service Primary Teachers' Knowledge and Efficacy. Australian Journal of Teacher Education, 38(5). doi: 10.14221/ajte.2013v38n5.4

Flores, I. M. (2015). Developing Preservice Teachers' Self-Efficacy through Field-Based Science Teaching Practice with Elementary Students. Research in Higher Education Journal, 27. Retrieved January $13^{\text {th }}$, 2020, from https://eric.ed.gov/?id=EJ1056173

Holland, S. M. (2008). Principal component analysis (PCA). Retrieved November 19, 2018, from https://strata.uga.edu/software/pdf/pcaTutorial.pdf

Hopkins, C. (2012). Twenty Years of Education for Sustainable Development. J. Educ. Sustain. Dev., $6,1-4$.

Mogensen, F., \& Schnack, K. (2010). The action competence approach and the 'new' discourses of education for sustainable development, competence and quality criteria. Environmental Education Research, 16(1), 59-74. doi: 10.1080/13504620903504032

Nielsen, J. A. (2017). Litteraturstudium til arbejdet med en national naturvidenskabsstrategi. [trans:literature study for the work with a national science strategy], Copenhagen.

OECD. (2009). Green at Fifteen? How 15-Year-Olds Perform in Environmental Science And Geoscience in Pisa 2006. doi: 978-92-64-06129-3

Prudon, P. (2015). Confirmatory factor analysis as a tool in research using questionnaires: a critique. Comprehensive Psychology, 4(10).

Rosseel, Y. (2012). lavaan: An R Package for Structural Equation Modeling. Journal of Statistical Software; Vol 1, Issue 2 (2012). doi: 10.18637/jss.v048.io2 
Sanchez, C., \& Dunning, D. (2018). Overconfidence among beginners: Is a little learning a dangerous thing? Journal of Personality and Social Psychology, 114(1), 10. Retrieved June $25^{\text {th }}, 2019$ from http://psycnet.apa.org/fulltext/2017-49272-001.html

Scott, W., Gough, S., \& Chalmers, S. N. (2003). Sustainable Development and Learning: Framing the issues. London: Routledge. doi: 10.4324/9780203464625

Sillasen, M., \& Linderoth, U. (2017). Tværfaglig undervisning i folkeskolens naturfag. [trans: Interdisciplinary teaching in public school science] MONA, 2O17(3), 19-38.

United Nations Educational, Scientific and Cultural Organization (UNESCO). ESD-Building a better, fairer world for the 21st century. Retrieved June 11, 2018 from https://unesdoc.unesco.org/ ark:/48223/pfoooo216673

United Nations. (2000). Millennium Declaration. Retrieved November 2, 2018, from http://www. un.org/millennium/declaration/ares552e.htm

United Nations. (2015a). Sustainable Development Goals. Retrieved November 2, 2018, from https://www.un.org/sustainabledevelopment/sustainable-development-goals/

United Nations. (2015b). Teach Millenium Goals. Retrieved November 18, 2018, from http://www. un.org/millenniumgoals/ 


\section{APPENDIX A}

Survey tool for mapping pre-service teacher students' readiness and efficacy to teach sustainability.

Dear science student

This is an investigation about your readiness to teach environmental issues, climate and sustainability. The answers that you give in this survey will be used to improve education for sustainability embedded in the teacher training programme

This is an anonymous survey and your answers will remain confidential. Your contribution is greatly valued. Thank you.

It takes 10-15 minutes to respond.

Age

(1) 20-25

(2) $26+$

Gender

(1) Female

(2) Male

Your primary science subject
(1) Biology
(2) Physics/chemistry
(3) Geography
(4) Nature/technology

What is your attitude towards the following statements?

\begin{tabular}{|l|l|l|l|l|l|}
\hline & $\begin{array}{l}\text { Strongly } \\
\text { agree }\end{array}$ & Agree & Neutral & Disagree & $\begin{array}{l}\text { Strongly } \\
\text { disagree }\end{array}$ \\
\hline $\begin{array}{l}\text { Q1: I am confident, that I can prepare accurate } \\
\text { teaching modules about our environment }\end{array}$ & $(1)$ & $(2)$ & $(3)$ & $(4)$ & $(5)$ \\
\hline $\begin{array}{l}\text { Q2: I cannot include education for the envi- } \\
\text { ronment in my teaching, because it needs to } \\
\text { be taught by specially trained teachers }\end{array}$ & $(1)$ & $(2)$ & $(3)$ & $(4)$ & $(5)$ \\
\hline $\begin{array}{l}\text { Q3: I have skills and knowledge that would } \\
\text { allow me to educate students about the } \\
\text { environment }\end{array}$ & $(1)$ & $(2)$ & $(3)$ & $(4)$ & $(5)$ \\
\hline $\begin{array}{l}\text { Q4: I am confident and able to include educa- } \\
\text { tion about our environment in my teaching }\end{array}$ & $(1)$ & $(2)$ & $(3)$ & $(4)$ & $(5)$ \\
\hline $\begin{array}{l}\text { Q5: It is important that primary/secondary } \\
\text { schools promote education for environment }\end{array}$ & $(1)$ & $(2)$ & $(3)$ & $(4)$ & $(5)$ \\
\hline $\begin{array}{l}\text { Q6: As teacher I can play an important role } \\
\text { in solving environmental challenges through } \\
\text { teaching }\end{array}$ & $(1)$ & $(2)$ & $(3)$ & $(4)$ & $(5)$ \\
\hline $\begin{array}{l}\text { Q7: It is very important to educate school } \\
\text { students about our environment from an } \\
\text { early age }\end{array}$ & $(1)$ & $(2)$ & $(3)$ & $(4)$ & $(5)$ \\
\hline
\end{tabular}


Do you know about...?

\begin{tabular}{|c|c|c|c|c|}
\hline \multicolumn{5}{|l|}{ Can you explain? } \\
\hline & $\begin{array}{l}\text { I have never } \\
\text { heard of this and } \\
\text { would not be } \\
\text { able to explain } \\
\text { it. }\end{array}$ & $\begin{array}{l}\text { I have heard about } \\
\text { this, but I would not } \\
\text { be able to explain } \\
\text { what it is really } \\
\text { about. }\end{array}$ & $\begin{array}{l}\text { I know something } \\
\text { about this and will be } \\
\text { able to explain the } \\
\text { general issue }\end{array}$ & $\begin{array}{l}\text { I am familiar } \\
\text { with this } \\
\text { and I would } \\
\text { be able to } \\
\text { explain it } \\
\text { well }\end{array}$ \\
\hline $\begin{array}{l}\text { Q8: Climate } \\
\text { change }\end{array}$ & (1) & (2) & (3) & (4) \\
\hline Q9: Energy supply & (1) & (2) & (3) & (4) \\
\hline $\begin{array}{l}\text { Q10: Drinking } \\
\text { water supply }\end{array}$ & (1) & (2) & (3) & (4) \\
\hline $\begin{array}{l}\text { Q11: Emission } \\
\text { of substances to } \\
\text { nature }\end{array}$ & (1) & (2) & (3) & (4) \\
\hline $\begin{array}{l}\text { Q12: Extinction of } \\
\text { species }\end{array}$ & (1) & (2) & (3) & (4) \\
\hline
\end{tabular}

Q13: What does sustainable development mean?

(1) Development which we can sustain without damaging the economy

(2) Development which meets the needs of people today without compromising the ability of future generations to meet their needs.

(3) Development which promotes crop production without the use of genetically modified organisms and pollutants

(4) Development of food production methods which support the food industry's economic basis

Q14: What is the biodiversity crisis about?

(1) A decrease in the total biomass of plants, animals and fungi on the ground

(2) A decrease in pollution-free areas in nature

(3) A decrease in the number of different species of plants, animals and fungi

(4) A decrease in the number of individuals of plants, animals and fungi

Q15: What is the main reason for climate change in the last decades?

(1) A hole in the earth's atmosphere

(2) Increased deforestation

(3) Increased cloud cover

(4) Increased carbon emissions

Q16: What is the main cause of oxygen depletion in coastal waters?

(1) Leaching of nutrient salts from agricultural areas and residential areas

(2) Wastewater discharge from industrial production

(3) Detergent of pesticides from conventional agricultural production

(4) Oil spill from ship traffic

Q17: What is the most common cause for species to go extinct in nature?

(1) They are killed by pesticides

(2) Their habitats are destroyed by humans 
(3) There is too much to hunting

(4) They are affected by climate change

Q18: Why are tropical rain forests important for the UN's sustainability goals?

(1) They cause heavy rainfall in otherwise very dry regions

(2) They contain valuable timber which can be logged sustainably

(3) They provide habitat for many different species

(4) They have particularly fertile soil

Q19: We can achieve a CO2-neutral energy production, but get radioactive waste if our energy source is:
(1) Uranium
(2) Coal
(3) Oil
(4) Natural gas

Q20: Where do man-made increases in carbon emissions come from?
(1) Incineration of fossil fuels
(2) Deforestation
(3) Leaching of nutrient salts from agricultural areas and residential areas
(4) An increased population of humans and production animals that emit $\mathrm{CO} 2$ and produce methane gas

Q21: What is the biggest threat to species resident in Denmark?
(1) Destruction of habitats due to intensive land use
(2) Use of pesticides in agricultural production
(3) Particle pollution and acid rain due to air pollution
(4) Pollution contamination

Q22: What has primarily reduced the ozone layer for decades?
(1) Burning of fossil fuels
(2) Pollution from the plastic industry
(3) Release of CFC gases into the atmosphere
(4) Increased surface temperature of the sun 